Publisher homepage: www.universepg.com, ISSN: 2663-7804 (Online) \& 2663-7790 (Print) https://doi.org/10.34104/ajeit.019.21030

Australian Journal of Engineering and Innovative Technology

Journal homepage: www.universepg.com/journal/ajeit

\title{
Comparison of the Quality Parameter between Cotton and Melange process
}

\author{
Rezaul Karim $^{1 *}$, Abdur Razzak ${ }^{1}$, A.K.M. Mahabubuzzaman ${ }^{2}$, and A Shahid ${ }^{3}$ \\ ${ }^{1}$ Dept. of Textile Engineering, Sonargaon University, Dhaka, Bangladesh; ${ }^{2}$ Bangladesh Jute Research Institute, Dhaka, \\ Bangladesh; ${ }^{3}$ Dept. of Textile Engineering, Dhaka University of Engineering \& Technology, Gazipur, Bangladesh \\ *Correspondence: rezatex99@gmail.com
}

\begin{abstract}
The comparison of quality parameter between Cotton and melange processes for different count and melange ratios have been studied. Here the yarns are produced from Indian cotton, Australia cotton, US cotton, China Black Viscose, and Indian Black Viscose (Melange). During the project work different properties for different machine in same setting and ratios have been observed. All observations have completed by latest model LMW (LR 9/AX) Auto Doffer Ring Machine. The quality parameters, for instance mass irregularity (U\%, CVm\%,) Imperfection index (IPI), Count Strength Product (CSP), and hairiness were tested and then analyzed. For melange yarn, for different ratios, the best results have been given by $100 \%$ cotton yarn, because there is no blending between two different fibers. The quality parameter and characteristics have been presented for different types of fiber (100\% cotton, Black Viscose) and produced yarn (100\% Cotton, 5\% Melange, 10\% Melange, and $15 \%$ Melange ratio) from the fiber. Productivity of melange yarn base on different condition is increased than $100 \%$ cotton yarn.
\end{abstract}

Keywords: Cotton, CSP, U\%, CVm\%, Melange, Imperfection, Quality Parameter, IPI, and Yarn

\section{INTRODUCTION}

Yarn is long continuous length of interlocked fibers that may be used in various applications. Spinning is ancient textile art where plant, animal or synthetic fibers are drawn out and then twisted together to form yarn. Yarn manufacturing draws our attention to the earliest days of the 19th century, when practically this was made possible by Ring Spinning. Flock dyeing cotton and the consequent mechanical processes lead to an increased amount of fibers that are damage in comparison to undyed fibers (Sharif et al., 2015). The spin ability of melange yarns in ring spinning is better than rotor spinning for the problems of deposition of detached particles on rotor groove. With increasing of dyed viscose in melange yarn, yarn irregularity, UniversePG I www.universepg.com imperfection, strength and elongation have been decreased (Neha, 2013). On the other hand, fabric GSM has been increased with high percentage of viscose fiber in melange yarn. Spindle speed 15500 gives better yarn evenness (Islam et al., 2019). As spindle speed increases, the yarn elongation has been decreased. For lower viscose percentage in melange yarn, higher spindle speed gives greater yarn strength.

Cotton Melange yarn quality is significantly affected by the method of blending (Cotton for Nonwovens). Better melange yarn quality is achieved with the draw frame blending techniques than with the blow room blending technique. Melange yarn quality significant deteriorates with increase in shade depth (\%) for both 
types of blending techniques. Polyester-flax blended yarn processing is very difficult due to problem of flax fiber processing (Lawrence H. Shaw, 1998). Generally require huge potential of energy in spun yarn production. They can play a vital role by time saving, cost effective and ensure to manufacture better quality yarn. This definitely would create a momentous influence in the spun yarn production if these technologies can be commercialized appropriately at the industrial sector (Tortora and Collier, 1997). However, further research is still required to bring successful commercialization of these concepts.

Dyed fiber component and spacer height impact are directly on the parameters of yarn (Kadolph, 1998). Dyed fiber component $\%$ in yarn has a greater effect on normal ring spun melange yarn as compare to ring compact spinning melange yarn. It was investigated that when there was reduction in the dyed component by $50 \%$. IPI also reduced, RKM increases, and $10 \%$ Uster \% decreases in normal melange yarn. In compact melange yarn contribution on the yarn properties of dyed fibre was lesser. Found that compact spinning system overcomes deterioration of yarn properties due to dyed components. The compact spinning system in melange also shows better properties like as U\%, IPI, RKM, Hairiness and friction over the normal spinning system. Compact melange yarn also shows very high elongation as compare to normal melange yarn which is an essential property for knitting. Blending of cotton with polyester fibers is considered as one of the most popular blending in the textile sector because of the wonderful aesthetic and functional properties that can be gained for the products made of them (Lawrence H. Shaw, 1998).

The physical properties of the bamboo/cotton blended yarn with similar $100 \%$ cotton yarn (The Classification of Cotton, USDA, cotton Division, Agricultural Handbook 566, September 1995). The bamboo- cotton blend ratios of each category of yarn (30s, 40s and 50s) were 67:33, 50:50, and 33:67, respectively. For each individual count of yarn, it was observed from the test result that the properties of 50:50/bamboo: cotton blended yarn showed very nearer property to the $100 \%$ cotton yarn. For Count (30s), 67: 33/ bamboo: cotton showed very closer property to the 50:50/bamboo: cotton blended yarn. It was also observed that for each count of yarns, which showed decreasing property with the increase of bamboo.

The quality character depends upon the ratio of bamboo and cotton in the blend and the effects of silk fiber when staple mulberry silk fiber is used to build yarns with cotton, and to find out the differences of these yarns' quality when they are produced with ring and siro systems (Robert Hooke, 1965). For this reason, $\mathrm{Ne} 40$ and $\mathrm{Ne} 20$ yarns were produced with ring spinning system and Ne 30 yarns were produced with both siro and ring spinning systems and then, results of various tests were gathered and investigated. In the study obtained that, in the studied factory is very low and is in the range of $75 \%$ to $95 \%$ Uster statistics. This is for to the fact that the factory has no the cultures of working with dynamic variations in cotton or polyester fibers. Spindle speed has significant effects on the melange yarn unevenness and imperfections (Ray et al., 2018). In this work, comparative study of the Quality Parameter between Cotton and melange process have been analyzed a unique work.

\section{MATERIALS AND METHODS}

Fibre Used in the Study: In the study two types of fibre was used such as Cotton Fibre, Shankar 6 super. Cotton fibres have a multilayered structure that has been studied for nearly a century. The structure of the primary cell wall of the cotton fibre and particularly the outer surface layer (the cuticle), has a major influence on fibre properties, processing and use. Shankar 6 fibre is the best quality cotton available only in Saurashtra Region of India. We purchase and process this category of cotton.

Processing of Spinning (Carded-Blended): Carding is a mechanical process that disentangles, cleans and intermixes fibres to produce a continuous web or sliver suitable for subsequent processing. This is achieved by passing the fibers between differentially moving surfaces covered with card clothing. The major steps involved in Spinning (Carded-Blended) following - 


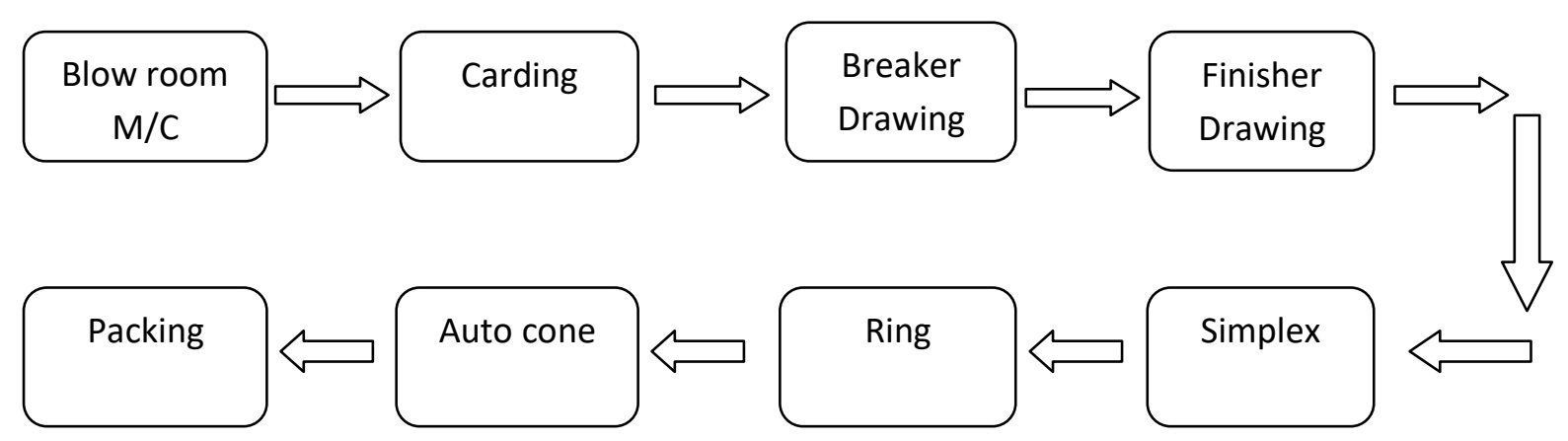

Fig 1: Flowchart of Spinning (Carded-Blended) Process.

\section{Used of Lab Equipment:}

Table 1: Instruments that's used in the experiment.

\begin{tabular}{|l|l|}
\hline M/C Name & Manufacturer \\
\hline Lea strength tester & MAG, INDIA \\
\hline USTER auto sorter 5 & Switzerland \\
\hline Digital twist tester & WIRA, UK \\
\hline Tachometer & England \\
\hline Hand held moister meter & England \\
\hline Auto yarn winder & MAG, INDIA \\
\hline Digital balance & USA \\
\hline Smart block & MAG, INDIA \\
\hline USTER ${ }^{\circledR}$ AFIS PRO & USA \\
\hline $\begin{array}{l}\text { USTER }{ }^{\circledR} \text { HVI } \\
\text { SPRECTRUM }\end{array}$ & USA \\
\hline USTER $^{\circledR}$ TESTER-5 & Switzerland \\
\hline Wrap reel & MAG,INDIA \\
\hline Moisture Meter & Germany \\
\hline
\end{tabular}

\section{RESULT AND DISCUSSION}

Yarn Evenness versus Process Ratio in Ring (26 Ne) - Sample preparation and working procedure for $26 \mathrm{Ne}$ yarn for $100 \%$ cotton, LGM 05\% LGM $10 \%$ and GM $15 \%$. In this work, we delivered cotton from Unifloc and Black viscose (melange) from Mixing bale Opener machine to Uniblend machine (in Blow room), it carried out the blended fiber automatically by the input setting (Required melange and cotton ratio) of specific ratio of blended fiber. Then it goes to carding through $\mathrm{MBO}$, Unistore and Condenser the above-mentioned ratio then carded sliver was carried out. These 8 slivers ( 82 grain/yd.) were passed through the breaker draw frame. Then delivered slivers (Each of 75 grain/yd.) fed to Finisher draw frame. From them 10 slivers (each of 70 grain/yd.) were taken. These 10 slivers were fed to simplex. From it 10 roving's $(0.78 \mathrm{Ne})$ ) were manufactured and creeled to the ring frame which is of 10 particular spindles. From the ring frame 10 ring cops of $26 \mathrm{Ne}$ LGM $05 \%$, LGM 10\%, GM 15\%, and $100 \%$ cotton yarn was spun. Finally, for testing all spun yarns were taken to QC dept.

Table 2: U\% of different melange ratio.

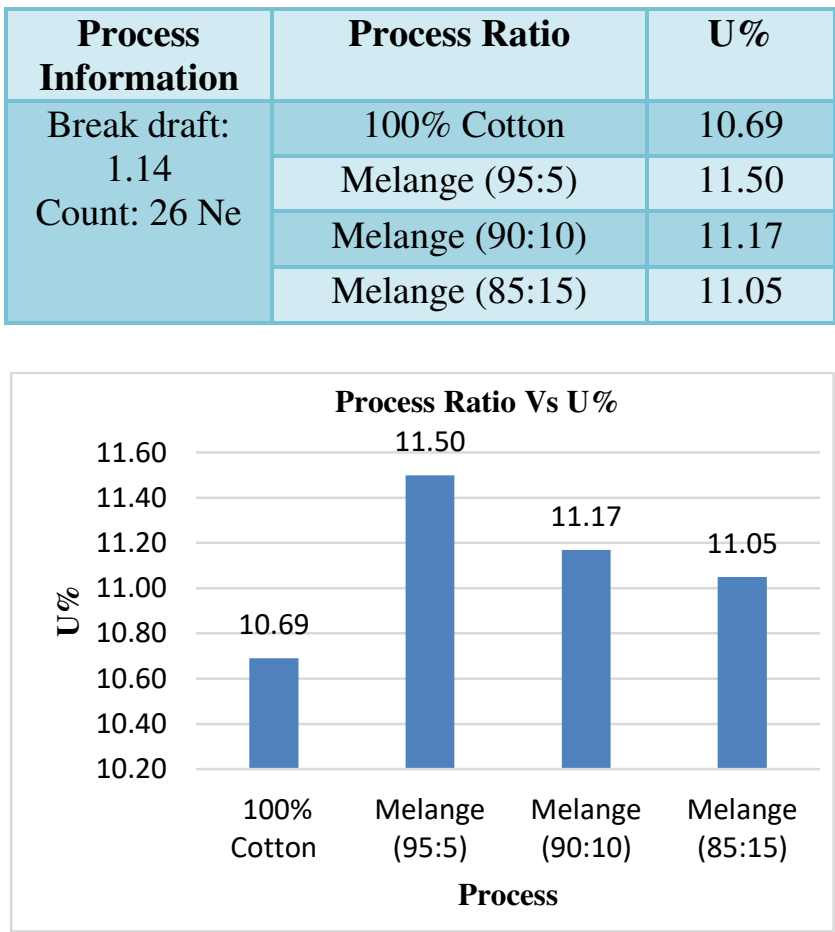

Fig 2: Comparison of U\% in different process ratio (100\% Cotton, melange 95/5, melange $90 / 10$ and melange 85/15) in Ring (Break draft: 1.14). 
The fig 2 shown above represents the relationship of unevenness (U \%) among $26 \mathrm{Ne} 100 \%$ Cotton yarn, $5 \%, 10 \%$ and $15 \%$ cotton-viscose melange yarn. It clearly revealed the graph that, U\% decreases gradually with the increase of viscose proportion in the yarn.

\section{Coefficient of Variation versus Process Ratio in Ring (26 Ne)}

Table 3: U\% of different melange ratio.

\begin{tabular}{|c|c|c|}
\hline $\begin{array}{c}\text { Process } \\
\text { Information }\end{array}$ & Process Ratio & $\mathbf{C V}_{\mathbf{m}} \%$ \\
\hline $\begin{array}{c}\text { Break } \\
\text { draft: } 1.14\end{array}$ & $100 \%$ Cotton & 13.60 \\
\hline \multirow{2}{*}{ Count: $26 \mathrm{Ne}$} & Melange (95:5) & 14.67 \\
\cline { 2 - 3 } & Melange (90:10) & 14.22 \\
\cline { 2 - 3 } & Melange (85:15) & 14.15 \\
\hline
\end{tabular}

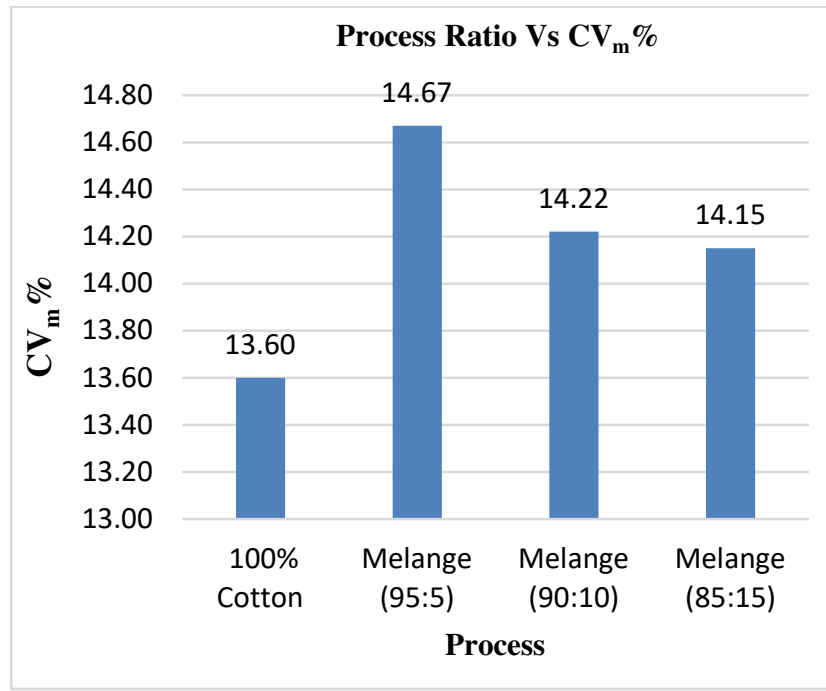

Fig 3: Comparison of $\mathrm{CV}_{\mathrm{m}} \%$ in different process ratio (100\% Cotton, melange 95/5, melange 90/10 and melange 85/15) in Ring (Break draft: 1.14).

The fig 3 shown above represents the relationship of unevenness (CV \%) among $26 \mathrm{Ne} 100 \%$ Cotton yarn, $5 \%, 10 \%$ and $15 \%$ cotton-viscose melange yarn. It clearly revealed the graph that, CV\% decreases gradually with the increase of viscose proportion in the yarn. The result attributed to the higher length, length uniformity and fineness of viscose fiber compared to the same of cotton. But the best result gives by $100 \%$ cotton yarn because there is no blending between two different fibers.
Thick $(+50 \%) / \mathbf{k m}$ versus Process Ratio in Ring (26 Ne)

Table 4: Thick place $(+50 \%) / \mathrm{Km}$ of different melange ratio.

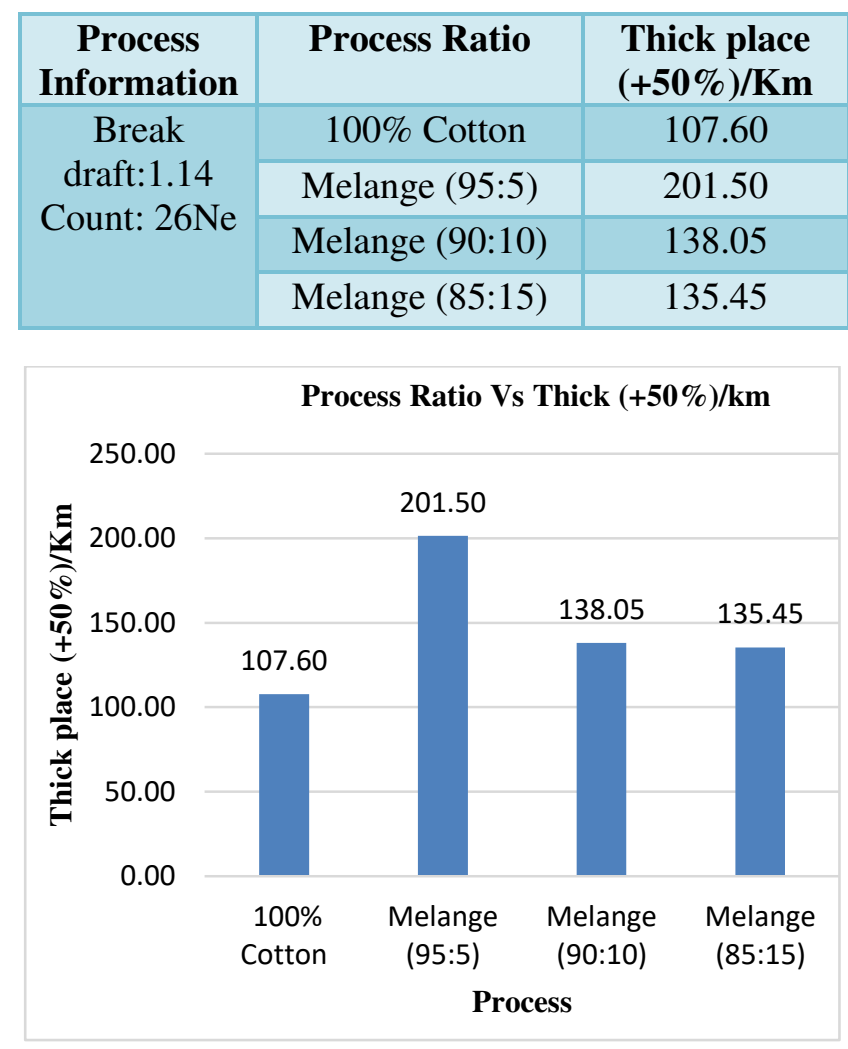

Fig 4: Comparison of Thick place $(+50 \%) / \mathrm{Km}$ in different process ratio (100\% Cotton, melange 95/5, melange 90/10 and melange 85/15) in Ring (Break draft: 1.14).

The fig 4 showed above represents the relationship of thick place (+50\%) among $26 \mathrm{Ne} 100 \%$ Cotton yarn, $5 \%, 10 \%$ and $15 \%$ cotton-viscose melange yarn. It clearly revealed the graph that, the lowest thick place found in $100 \%$ cotton. LGM 5\% melange yarn has thicker place than $100 \%$ cotton yarn because blending produces more short fibers. The short fiber is the prime factor of thick place and thin places. Thick places decrease with the increase of viscose fibers (due to decreasing the amount of short fibers in the fiber blends of higher percentage of viscose fiber).

Thin (-50\%)/ $\mathbf{k m}$ versus Process Ratio in Ring (26 $\mathrm{Ne})$ 
Table 5: Thin place $(-50 \%) / \mathrm{Km}$ of different melange ratio.

\begin{tabular}{|c|c|c|}
\hline $\begin{array}{c}\text { Process } \\
\text { Information }\end{array}$ & Process Ratio & $\begin{array}{c}\text { Thin place } \\
\mathbf{( - 5 0 \% ) / K m}\end{array}$ \\
\hline $\begin{array}{c}\text { Break } \\
\text { draft:1.14 } \\
\text { Count: } 26 \mathrm{Ne}\end{array}$ & Melange (95:5) & 143.80 \\
\cline { 2 - 3 } & Melange (90:10) & 106.80 \\
\cline { 2 - 3 } & Melange (85:15) & 86.30 \\
\hline
\end{tabular}

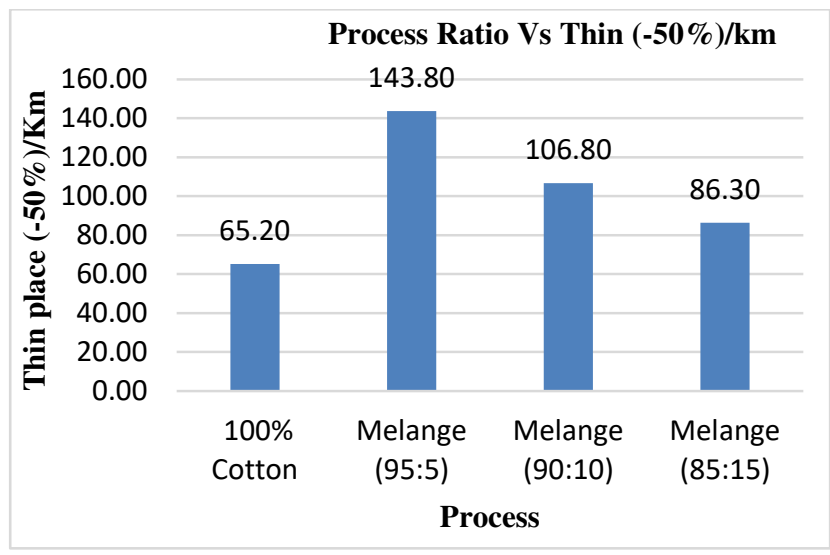

Fig 5: Comparison of Thin place $(-50 \%) / \mathrm{Km}$ in different process ratio (100\% Cotton, melange 95/5, melange 90/10 and melange 85/15) in Ring

(Break draft: 1.14).

The fig 5 shown above represents the relationship of thin place (-50\%) among $26 \mathrm{Ne} 100 \%$ Cotton yarn, $5 \%, 10 \%$ and $15 \%$ cotton-viscose melange yarn. It clearly revealed the graph that, the LGM 5\% melange yarn has thinner place than $100 \%$ cotton yarn because blending produces more short fibers.

\section{Neps $(+200 \%) / \mathrm{Km}$ versus Process Ratio in Ring $(26 \mathrm{Ne})$}

Table 6: Neps $(+200 \%) / \mathrm{km}$ of different melange ratio.

\begin{tabular}{|c|c|c|}
\hline $\begin{array}{c}\text { Process } \\
\text { Information }\end{array}$ & Process Ratio & $\begin{array}{c}\text { Neps } \\
(\mathbf{+ 2 0 0 \%}) / \mathbf{K m}\end{array}$ \\
\hline $\begin{array}{c}\text { Break } \\
\text { draft:1.14 }\end{array}$ & $100 \%$ Cotton & 58.20 \\
\hline Count: $26 \mathrm{Ne}$ & Melange (95:5) & 170.50 \\
\cline { 2 - 3 } & Melange (90:10) & 119.30 \\
\cline { 2 - 3 } & Melange (85:15) & 112.80 \\
\hline
\end{tabular}

The short fiber is the prime factor of thick place and thin places. There decreasing thin places in the blend yarn with the increasing viscose fibers due to decreasing the number of short fibers in the blend of higher percentage of viscose fiber (Fig 5).

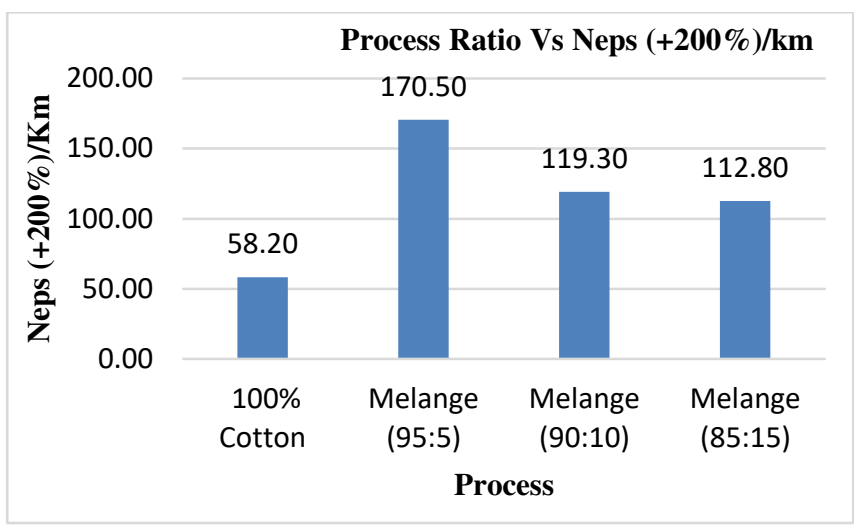

Fig 6: Comparison of Neps $(+200 \%) / \mathrm{km}$ in different process ratio (100\% Cotton, melange 95/5, melange 90/10 and melange 85/15) in Ring

(Break draft: 1.14).

The fig 6 showed above represents the strong relationship of Neps (+200\%) among $26 \mathrm{Ne} 100 \%$ Cotton yarn, $5 \%, 10 \%$ and $15 \%$ cotton-viscose melange yarn. It clearly revealed the graph that, Neps in cotton created during the mechanical harvesting and ginning. Also, over processing in the blowroom generates neps. Cotton contains immature fibres, biological communication i.e seed coat fragments, burk and stickness so bale cotton contains huge neps. Viscose fiber in the bale contains no neps. As a result, nep contain in blend yarn decreases with the gradual increase in viscose \%. But $100 \%$ cotton yarn contain lowest amount of neps because of no blending. In blending some extra neps produce in hand mixing and others were mixing.

\section{Imperfection Index versus Process Ratio in Ring (26 Ne)}

Table 7: Imperfection Index of different melange ratio.

\begin{tabular}{|c|c|c|}
\hline $\begin{array}{c}\text { Process } \\
\text { Information }\end{array}$ & Process Ratio & $\begin{array}{c}\text { Imperfection } \\
\text { Index }\end{array}$ \\
\hline $\begin{array}{c}\text { Break } \\
\text { draft:1.14 }\end{array}$ & $100 \%$ Cotton & 166.10 \\
\hline Count: $26 \mathrm{Ne}$ & Melange (95:5) & 374.30 \\
\cline { 2 - 3 } & Melange (90:10) & 258.82 \\
\cline { 2 - 3 } & Melange (85:15) & 250.05 \\
\hline
\end{tabular}




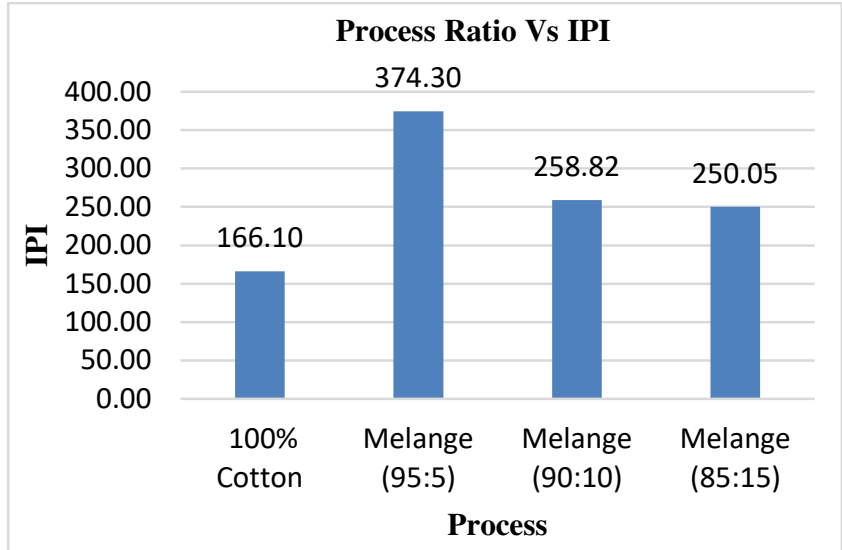

Fig 7: Comparison of Imperfection Index in different process ratio ( $100 \%$ Cotton, melange 95/5, melange 90/10 and melange 85/15) in Ring

(Break draft: 1.14).

The fig 7 shown above represents the relationship of Imperfection Index among $26 \mathrm{Ne} 100 \%$ Cotton yarn, $5 \%, 10 \%$ and $15 \%$ cotton-viscose melange yarn. Imperfection Index is the total number of thick place $(+50 \%)$, thin place $(-50 \%)$ and Neps $(+200 \%)$ for ring spun yarn. It is observed that imperfection, it clearly revealed the graph that, the lowest amount of thick place found in $100 \%$ cotton. LGM 5\% melange yarn has thicker place than $100 \%$ cotton yarn because blending produces more short fibers.

The short fiber is the prime factor of thick place and thin places. There the number of decreasing thick places with the increasing viscose fibers due to decreasing the amount of short fibers in the fiber blends of higher percentage of viscose fiber.

\section{Count Strength Product versus Process Ratio in Ring (26 Ne)}

Table 8: Count Strength Product of different melange ratio.

\begin{tabular}{|c|c|c|}
\hline $\begin{array}{c}\text { Process } \\
\text { Information }\end{array}$ & Process Ratio & $\begin{array}{c}\text { Count } \\
\text { Strength } \\
\text { Product }\end{array}$ \\
\hline $\begin{array}{c}\text { Break } \\
\text { draft:1.14 } \\
\text { Count: } 26 \mathrm{Ne}\end{array}$ & Melange (95:5) & 2298.65 \\
\cline { 2 - 3 } & Melange (90:10) & 2295.45 \\
\cline { 2 - 3 } & Melange (85:15) & 2261.35 \\
\hline
\end{tabular}

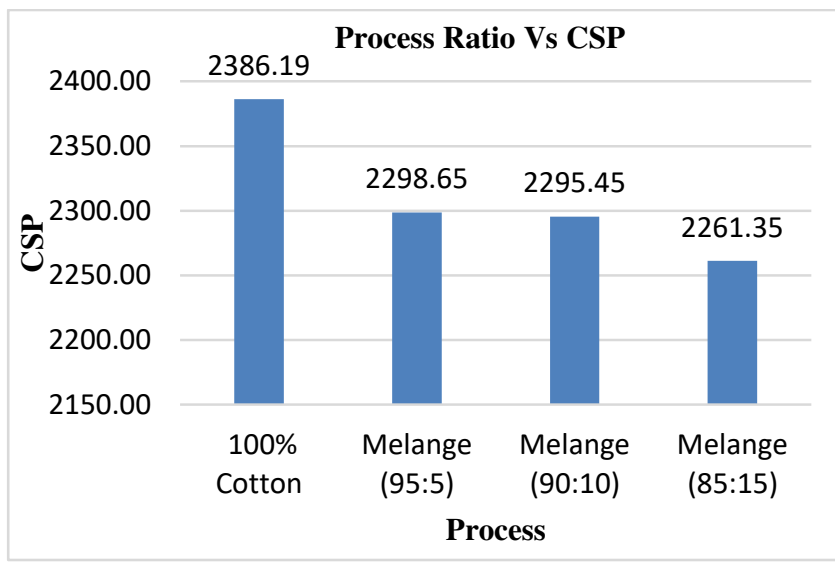

Fig 8: Comparison of Count Strength Product in different process ratio (100\% Cotton, melange 95/5, melange 90/10 and melange 85/15) in Ring (Break draft: 1.14).

The fig 8 shown above represents the CSP values of the various blend ratio of melange yarn. The graph reveals that increase in viscose proportion decrease the CSP value of Viscose cotton blended melange yarn. This occurs because of low strength of viscose fiber. Normally generated fibers have low strength than cotton fiber so that in CSP result shows $100 \%$ cotton yarn have higher CSP value. Then it is gradually decreasing when viscose percentage increases.

Yarn Evenness versus Process Ratio in Ring (30 Ne) - Sample preparation and working procedure for $30 \mathrm{Ne}$ yarn for $100 \%$ cotton, LGM 05\% LGM $10 \%$ \& GM $15 \%$. In this work, we delivered cotton from Unifloc and Black viscose (melange) from Mixing bale Opener machine to Uniblend machine (in Blow room), it carried out the blended fiber automatically by the input setting (Required melange and cotton ratio) of specific ratio of blended fiber. Then it goes to carding through $\mathrm{MBO}$, Unistore and Condenser the above-mentioned ratio then carded sliver was carried out. These 8 slivers (82 grain/yd.) were passed through the breaker draw frame. Then delivered slivers (Each of 75 grain/yd.) fed to Finisher draw frame. From them 10 slivers (each of 70 grain/yd.) were taken. From the ring frame 10 ring cops of 30 Ne LGM 05\%, LGM 10\%, GM 15\%, and 100\% cotton yarn were spun. Finally, all spun yarns were taken to QC department for testing. 
Table 9: U\% of different melange ratio.

\begin{tabular}{|c|c|c|}
\hline $\begin{array}{c}\text { Process } \\
\text { Information }\end{array}$ & Process Ratio & U\% \\
\hline $\begin{array}{c}\text { Break } \\
\text { draft:1.14 }\end{array}$ & $100 \%$ Cotton & 12.08 \\
\hline Count: $30 \mathrm{Ne}$ & Melange (95:5) & 11.01 \\
\cline { 2 - 3 } & Melange (90:10) & 11.62 \\
\cline { 2 - 3 } & Melange (85:15) & 10.94 \\
\hline
\end{tabular}

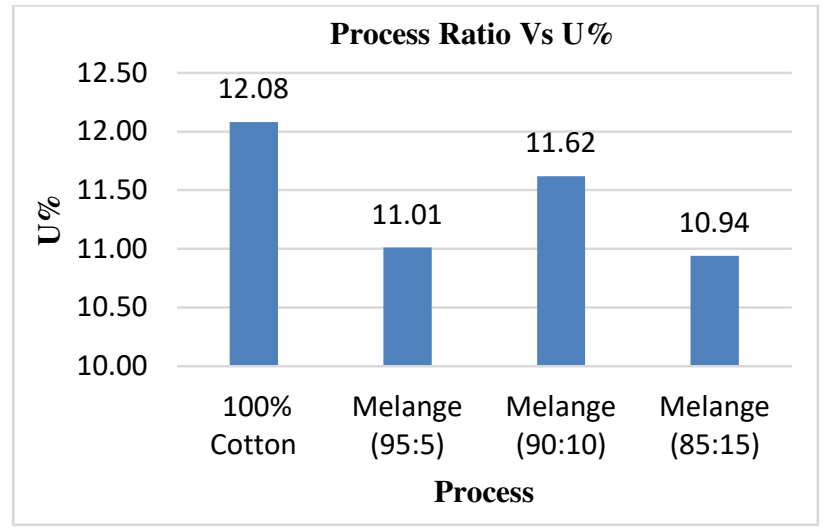

Fig 9: Comparison of U\% in different process ratio (100\% Cotton, melange 95/5, melange 90/10 and melange 85/15) in Ring (30 Ne).

The fig 9 shown above represents the relationship of unevenness (U \%) among $30 \mathrm{Ne} 100 \%$ Cotton yarn, $5 \%, 10 \%$ and $15 \%$ cotton-viscose melange yarn. It clearly revealed the graph that, $\mathrm{U} \%$ fluctuate gradually with the increase of viscose proportion in the yarn.

\section{Coefficient of Variation versus Process Ratio in Ring (30 Ne)}

Table 10: $\mathrm{CV}_{\mathrm{m}} \%$ of different melange ratio.

\begin{tabular}{|c|c|c|}
\hline $\begin{array}{c}\text { Process } \\
\text { Information }\end{array}$ & Process Ratio & $\mathbf{C V}_{\mathbf{m}} \%$ \\
\hline $\begin{array}{c}\text { Break } \\
\text { draft:1.14 }\end{array}$ & $100 \%$ Cotton & 15.70 \\
\hline $\begin{array}{c}\text { Count: } 30 \\
\text { Ne }\end{array}$ & Melange (95:5) & 14.04 \\
\hline & Melange (90:10) & 14.89 \\
\hline
\end{tabular}

The Fig 10 shown above represents the relationship of Coefficient of Variation $\left(\mathrm{CV}_{\mathrm{m}} \%\right)$ among $30 \mathrm{Ne}$ $100 \%$ Cotton yarn, $5 \%, 10 \%$ and $15 \%$ cotton-viscose melange yarn. If melange percentage is more then it reduces the coefficient of variation.

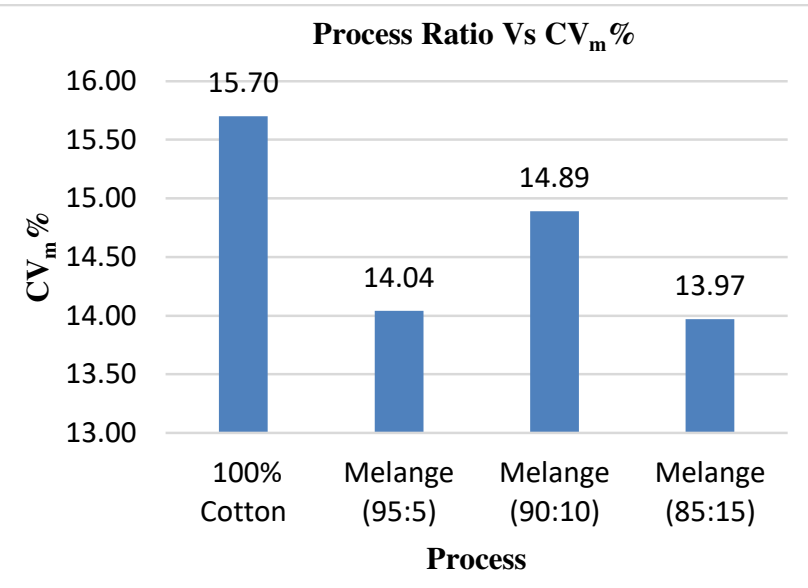

Fig 10: Comparison of $\mathrm{CV}_{\mathrm{m}} \%$ in different process ratio (100\% Cotton, melange 95/5, melange 90/10 and melange 85/15) in Ring (30 Ne).

It clearly revealed the graph that, $\mathrm{CV}_{\mathrm{m}} \%$ fluctuates gradually for the increase of viscose proportion in the yarn (Fig 10).

\section{Thick $(+50 \%) / \mathbf{k m}$ versus Process Ratio in Ring (30 Ne)}

Table 11: Thick place $(+50 \%) / \mathrm{Km}$ of different melange ratio.

\begin{tabular}{|c|c|c|}
\hline $\begin{array}{c}\text { Process } \\
\text { Information }\end{array}$ & Process Ratio & $\begin{array}{c}\text { Thick place } \\
(\mathbf{+ 5 0 \%}) / \mathbf{K m}\end{array}$ \\
\hline $\begin{array}{c}\text { Break } \\
\text { draft:1.14 } \\
\text { Count: } 30 \mathrm{Ne}\end{array}$ & 100\% Cotton & 257.00 \\
\cline { 2 - 3 } & Melange (95:5) & 145.00 \\
\cline { 2 - 3 } & Melange (90:10) & 236.00 \\
\hline
\end{tabular}

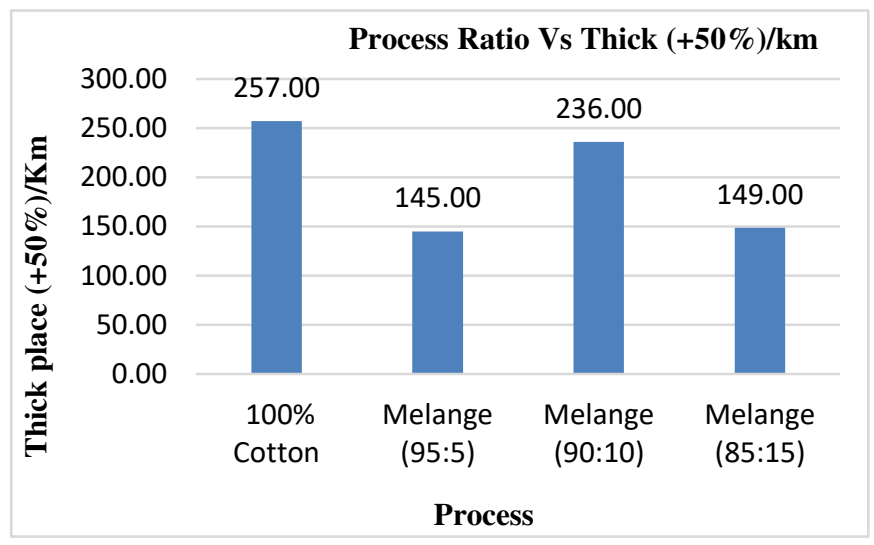

Fig 11: Comparison of Thick place $(+50 \%) / \mathrm{Km}$ in different process ratio (100\% Cotton, melange 95/5, melange 90/10 and melange 85/15) in Ring $(30 \mathrm{Ne})$ 
The fig 11 showed above represents the relationship of thick place $(+50 \%)$ among $30 \mathrm{Ne} 100 \%$ Cotton yarn, 5\%, 10\% and 15\% cotton-viscose melange yarn. It clearly revealed the graph that, lowest amount of thick place found in LGM 5\% melange yarn and has thicker place found in $100 \%$ cotton yarn because cotton produce more short fibers. The short fiber is the prime factor of thick place and thin places.

\section{Thin (-50\%)/ $\mathrm{km}$ versus Process Ratio in Ring (30} $\mathrm{Ne})$

Table 12: Thin place $(-50 \%) / \mathrm{Km}$ of different melange ratio.

\begin{tabular}{|c|c|c|}
\hline $\begin{array}{c}\text { Process } \\
\text { Information }\end{array}$ & Process Ratio & $\begin{array}{c}\text { Thin place } \\
\mathbf{( - 5 0 \% ) / K m}\end{array}$ \\
\hline $\begin{array}{c}\text { Break } \\
\text { draft:1.24 } \\
\text { Count: } 30 \mathrm{Ne}\end{array}$ & Melange (95:5) & 5.00 \\
\cline { 2 - 3 } & Melange (90:10) & 3.00 \\
\cline { 2 - 3 } & Melange (85:15) & 1.00 \\
\hline
\end{tabular}

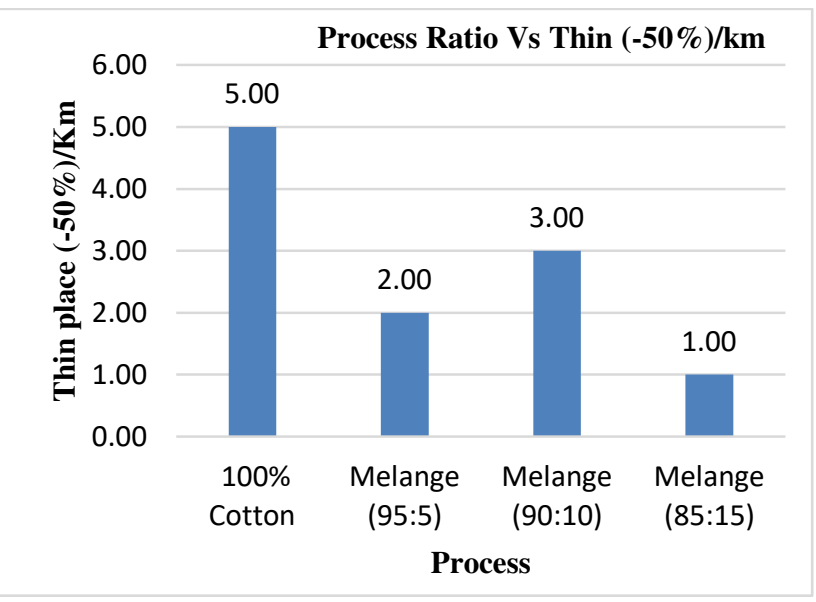

Fig 12: Comparison of Thin place $(-50 \%) / \mathrm{Km}$ in different process ratio (100\% Cotton, melange 95/5, melange 90/10 and melange 85/15) in Ring $(30 \mathrm{Ne})$

The fig 12 shown above represents the relationship of thin place (-50\%) among $26 \mathrm{Ne} 100 \%$ Cotton yarn, $5 \%, 10 \%$ and $15 \%$ cotton-viscose melange yarn. It clearly revealed the graph that, $100 \%$ cotton yarn has thinner place than other ratio of melange yarn because of more short fibers in cotton. The short fiber is the prime factor of thick place and thin places.
There the number, decreasing thin places in the blend yarn with the increasing viscose fibers due to decreasing the amount of short fiber in the fiber blend of higher percentage of viscose fiber.

Neps $(+200 \%) / \mathrm{Km}$ versus Process Ratio in Ring $(30 \mathrm{Ne})$

Table 13: Neps $(+200 \%) / \mathrm{km}$ of different melange ratio.

\begin{tabular}{|c|c|c|}
\hline $\begin{array}{c}\text { Process } \\
\text { Information }\end{array}$ & Process Ratio & $\begin{array}{c}\text { Neps } \\
(+200 \%) / K m\end{array}$ \\
\hline $\begin{array}{c}\text { Break } \\
\text { draft:1.14 } \\
\text { Count:30Ne }\end{array}$ & Melange (95:5) & $160 \%$ Cotton \\
\cline { 2 - 3 } & Melange (90:10) & 295.00 \\
\cline { 2 - 3 } & Melange (85:15) & 163.00 \\
\hline
\end{tabular}

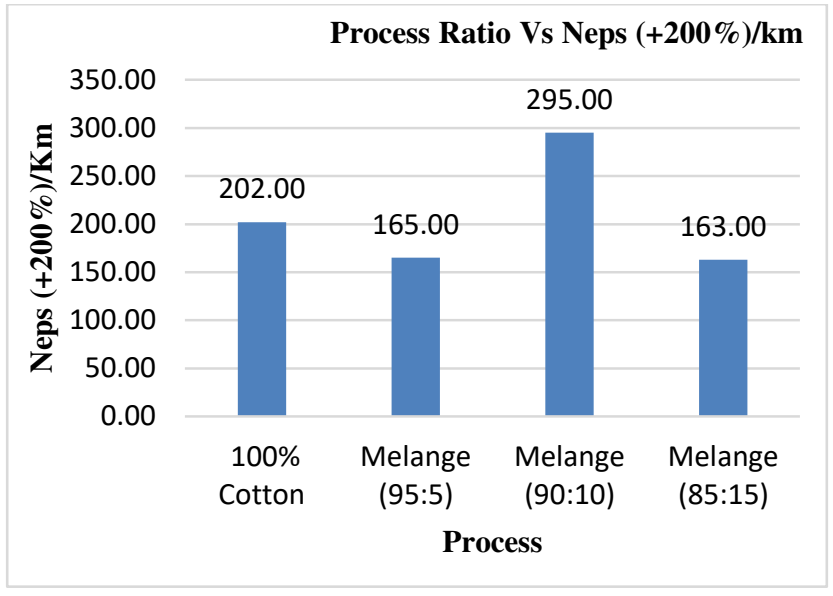

Fig 13: Comparison of Neps $(+200 \%) / \mathrm{km}$ in different process ratio (100\% Cotton, melange 95/5, melange 90/10 and melange 85/15) in Ring $(30 \mathrm{Ne})$

The fig 13 showed above represents the strong relationship of Neps (+200\%) among $30 \mathrm{Ne} 100 \%$ Cotton yarn, $5 \%, 10 \%$ and $15 \%$ cotton-viscose melange yarn. Over processing in the blowroom generates neps. Cotton contains immature fibres, biological communication i.e seed coat fragments, burk and stickness so bale cotton contains huge neps. Viscose fibers in the bale contain no neps. But LGM $10 \%$ produce more neps due to in the interaction of blow room and carding machine in hand mixing and others mixing. But $100 \%$ cotton yarn contain about lowest amount of neps because of no blending. 


\section{Imperfection Index versus Process Ratio in Ring} $(30 \mathrm{Ne})$

Table 14: Imperfection Index of different melange ratio.

\begin{tabular}{|c|c|c|}
\hline $\begin{array}{c}\text { Process } \\
\text { Information }\end{array}$ & Process Ratio & $\begin{array}{c}\text { Imperfection } \\
\text { Index }\end{array}$ \\
\hline $\begin{array}{c}\text { Break } \\
\text { draft:1.24 }\end{array}$ & 100\% Cotton & 463.00 \\
\hline \multirow{2}{*}{ Count: $30 \mathrm{Ne}$} & Melange (95:5) & 312.00 \\
\cline { 2 - 3 } & Melange (90:10) & 534.00 \\
\cline { 2 - 3 } & Melange (85:15) & 313.00 \\
\hline
\end{tabular}

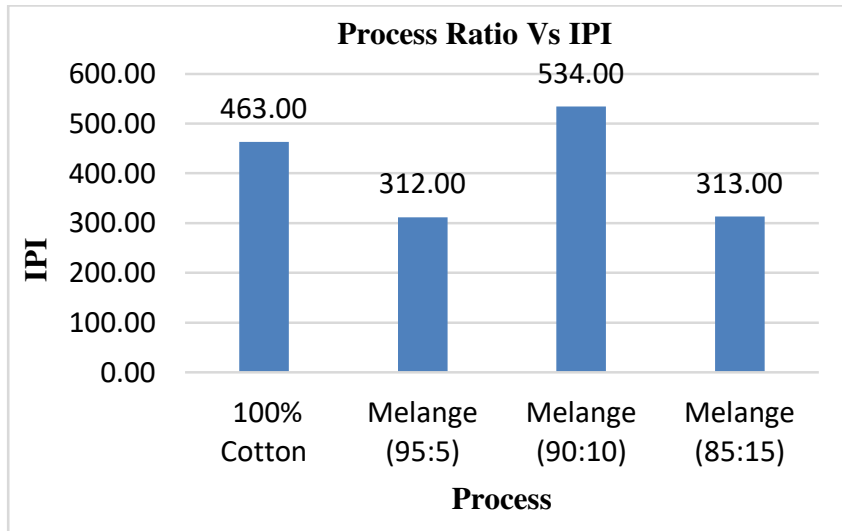

Fig 14: Comparison of Imperfection Index in different process ratio (100\% Cotton, melange 95/5, melange 90/10 and melange 85/15) in Ring $(30 \mathrm{Ne})$.

The figure shown above represents the relationship of Imperfection Index among $30 \mathrm{Ne} 100 \%$ Cotton yarn, $5 \%, 10 \%$ and $15 \%$ cotton-viscose melange yarn. Imperfection Index is the total number of thick place $(+50 \%)$, thin place $(-50 \%)$ and Neps $(+200 \%)$ for ring spun yarn.

\section{Count Strength Product versus Process Ratio in Ring (30 Ne)}

Table 15: Count Strength Product of different melange ratio.

\begin{tabular}{|c|c|c|}
\hline $\begin{array}{c}\text { Process } \\
\text { Information }\end{array}$ & Process Ratio & $\begin{array}{c}\text { Count Strength } \\
\text { Product }\end{array}$ \\
\hline $\begin{array}{c}\text { Break } \\
\text { draft:1.24 }\end{array}$ & $100 \%$ Cotton & 2386.19 \\
\hline Count: $30 \mathrm{Ne}$ & Melange (95:5) & 2298.65 \\
\cline { 2 - 3 } & Melange (90:10) & 2295.45 \\
\cline { 2 - 3 } & Melange (85:15) & 2261.35 \\
\hline
\end{tabular}

It is observed that imperfection, it clearly revealed the graph that, the lowest amount of thick place found in LGM 5\% melange yarn and has thicker place, Neps in LGM 5\% melange yarn so more IPI has of LGM $10 \%$ melange yarn (Fig 14).

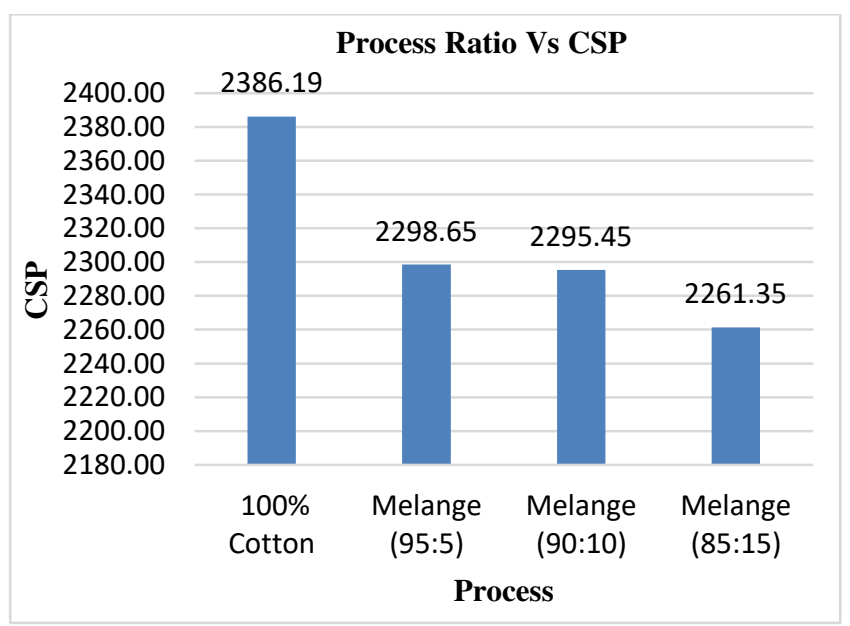

Fig 15: Comparison of Count Strength Product in different process ratio (100\% Cotton, melange $95 / 5$, melange $90 / 10$ and melange $85 / 15$ ) in Ring $(30 \mathrm{Ne})$.

The figure shown above represents the CSP values of the various blend ratio of melange yarn. The graph reveals that increase in viscose proportion decrease the CSP value of Viscose cotton blended melange yarn. This occurs because of low strength of viscose fiber. Normally generated fibers have low strength than cotton fiber so that in CSP results in shows $100 \%$ cotton yarn have higher CSP value. Then it is gradually decreased when viscose percentage increase.

\section{CONCLUSION}

Yarn quality depends on many factors. Short fibers, immature fiber, natural fiber, manmade fiber, semi manmade fiber showed the different result for same quality parameter. Actually, fiber length influences all results of yarn. If short fiber increases then yarn quality must be deteriorated. This deteriorate can be minimized by different way. Proper break draft selection of ring frame is one of them. In this thesis it was found, yarn $\mathrm{U} \%, \mathrm{CVm} \%$, thin places, thick places, neps results can be improved by changing the different manmade (Black-viscose) ratio of fiber with 
cotton. Though we would try to take better result from the experiment but have some limitations, like we could not ensure the same fiber length of cotton and viscose, solubility test was not available etc. Finally, we concluded as: i) Yarn results of $\mathrm{Ne} 26$ carded, observed that lowest amount of thick place found in $100 \%$ cotton. LGM 5\% melange yarn has thicker place than $100 \%$ cotton yarn because blending produces more short fibers. ii) Lowest amount of thick place found in $100 \%$ cotton. LGM $5 \%$ melange yarn has thicker place than $100 \%$ cotton yarn because blending produces more short fibers.iii) Yarn results of $\mathrm{Ne} 30$ carded, observed that imperfection, it clearly revealed, lowest amount of thick place found in LGM 5\% melange yarn and has thicker place, Neps in LGM 5\% melange yarn so more IPI has of LGM $10 \%$ melange yarn.

\section{ACKNOWLEDGEMENT}

We are greatly acknowledged to Reedisha Blended Yarn Ltd., Jamirdia, Valuka, and Mymensingh, Bangladesh where this research work has been performed. The authors would like to convey their heartiest thanks to all officers and lab assistants in Reedisha Blended Yarn Ltd. for their continuous support and help to make this work a successful.

\section{CONFLICTS OF INTEREST}

The authors declare they have no competing interests with respect to the research.

\section{REFERENCES}

1) Ahmed Sharif, Syduzzaman Md, Mahmud Md. Sultan, Rahman and Mohammad Mahbubur (2015). Comparative study on ring, rotor and air-jet spun yarn, European
Scientific Journal, 11(3), 411-424.

2) Cotton for Nonwovens, A Technical Guide, and Cotton Incorporated.

https://www.cottoninc.com/quality-produc ts/nonwovens/cotton-fiber-tech-guide/

3) Gupta Neha (2013). Analysis on the Defects in Yarn Manufacturing Process \& its Prevention in Textile Industry, International J. of Engineering Inventions, 2(7), 45-67.

4) Kadolph, S.J., Langfold, and A. J., (1998). Textiles, 8th edition, Prentice-Hall.

5) Islam KA, Deeba F, and Hassan MKA. (2019). Dust Ion Acoustic Solitary Waves in Multi-Ion Dusty Plasma System with Adiabatic Thermal Change, Aust. J. Eng. Innov. Technol., 1(5), 1-5. https://doi.org/10.34104/ajeit.019.0105

6) Lawrence H. Shaw (1998). "Cotton's Importance in the Textile Industry", Symposium, Lima, Peru.

7) Robert Hooke (1965). Fine Silk, or Taffety in Micrographia, (London: Constable and Company, 196), p. 7.

8) Suchibrata Ray, Anindya Ghosh, Debamalya Banerjee (2018) "Analyzing the effect of Spinning process variables on blow room blended cotton melange yarn quality", Research Journal of Textile and Apparel, 22(1), 2-14.

https://doi.org/10.1108/RJTA-05-2017-0019

9) The Classification of Cotton, USDA, cotton Division, Agricultural Handbook 566, September 1995.

10) Tortora P. G. and Collier B.J. (1997). Understanding Textiles, $5^{\text {th }}$ edition, PrenticeHall.

Citation: Karim R, Razzak A, Mahabubuzzaman AKM, and Shahid A. (2019). Comparison of the quality parameter between cotton and melange process, Aust. J. Eng. Innov. Technol., 1(6), 21-30. https://doi.org/10.34104/ajeit.019.21030 @) 